\title{
Enhanced removal of cationic dye by eco-friendly activated biochar derived from rice straw
}

\author{
A. I. Abd-Elhamid ${ }^{1}$ (D) Mohamed Emran ${ }^{2} \cdot$ M. H. El-Sadek ${ }^{3} \cdot$ Ahmed A. El-Shanshory $^{1} \cdot$ Hesham M. A. Soliman $^{1}$. \\ M. A. Akl ${ }^{4} \cdot$ Mohamed Rashad ${ }^{2}$
}

Received: 1 November 2018 / Accepted: 23 December 2019 / Published online: 3 January 2020

(c) The Author(s) 2020

\begin{abstract}
This report deals with converting the agriculture waste (rice straw) to environmental cleaner materials (biochar) using airless pyrolysis followed by eco-friendly activation. The biochar (p-Biochar) obtained after pyrolysis step (poorly active material) was activated using wet attrition method to give m-Biochar (highly active materials). The both p-Biochar and m-Biochar were characterized in detail and utilized for $\mathrm{MB}$ and $\mathrm{CV}$ dye removal from aqueous solution. Various parameters affecting the adsorption process such as dye concentration, adsorbent dose, contact time, temperature, $\mathrm{NaCl}$ dose and $\mathrm{pH}$ were investigated. The adsorption isotherm was well fitted using Langmuir isotherm, and the maximum adsorption capacity is 90.91 and $44.64 \mathrm{mg} / \mathrm{g}$, for MB and CV dyes, respectively. The contact time data obtained showed that the two dyes were poorly adsorbed over p-Biochar. The equilibrium was reached quickly in $15 \mathrm{~min}$ for MB dye and $20 \mathrm{~min}$ for $\mathrm{CV}$ dye using the m-Biochar, and removal percent was 94.45 and $92.70 \%$ for MB and CV dyes, respectively. Moreover, the kinetic isotherm presented very well fitted by pseudo-second-order model. In addition, the adsorption percent increases with further increasing the $\mathrm{pH}$ value. Finally, we observed that $\mathrm{m}$-Biochar highly adsorbs the MB dye compared with the CV dye over all experimental conditions.
\end{abstract}

Keywords Biochar $\cdot$ Eco-friendly $\cdot$ Removal $\cdot$ Water $\cdot$ Treatment

\section{Introduction}

Dyes are considered as colored ionized aromatic organic materials. Dyes are required by numerous industries such as textile, leather, paper, plastic, and food. The effluents from these industries contain various types of contaminated, dye

A. I. Abd-Elhamid

ahm_ch_ibr@yahoo.com

1 Advanced Technology and New Materials Research Institute, City of Scientific Research and Technological Applications (SRTA-City), P. O. Box 21934, Alexandria, Egypt

2 Land and Water Technologies Department, Arid Lands Cultivation Research Institute (ALCRI), City of Scientific Research and Technological Applications (SRTA-City), New Borg El-Arab City, Alexandria, Egypt

3 Pyrometallurgy Department, Minerals Technology Division, Central Metallurgical R\&D Institute (CMRDI), P. O. Box 87, Cairo, Egypt

4 Chemistry Department, Mansoura University, Mansoura, Egypt is one of the major involvement (Kobylewski and Jacobson 2010). The discharging of such contaminants in the environment causes a bad effect on human being, fish species, and microorganisms (Gupta 2009). Most of dyes are toxic, carcinogenic or mutagenic and can pose a hazard to health. Hence, it is very important to treat the dyed aquatic wastewater.

Several techniques were investigated to remove the dye species from the wastewater (Srinivasan and Viraraghavan 2009). Adsorption is considered a promising technique, in which the contaminants were transferred from the solvent to the solid phase. Based on this consideration, the adsorption appears to be simple to design, available, easy to operate, does not produce toxic materials and does not require high cost.

Activated carbon is the most applicable adsorbent used in industry; this is attributed to its adsorptive efficiency, high surface area, and porous structure. Nowadays, there is a great attention to prepare the low-cost activated carbon from alternative sources. Many researchers have prepared activated carbon from various waste agriculture products 
such as orange peel (Khaled et al. 2009), coconut tree (Senthilkumaar et al. 2006), coffee husk (Ahma and Rahman 2011), coconut husk (Foo and Hameed 2012; Aljeboree et al. 2017), pine cone (Gecgel and Kolancilar 2012), black acacia bark wastes (Da Silva et al. 2018), and rice husk (Rahman et al. 2012).

Rice straw can be considered as the most common biomass agricultural waste in the Egyptian Nile delta regions. Its production is quantified as 4 million tons per year. In the last decade, burning this in huge quantities by farmers has added an additional source of greenhouse gases (GHG) emitted from agricultural sector and caused "the black cloud," a thick black smog that can be seen over the Cairo sky every autumn. Converting this agricultural waste to biochar based on its content of $43 \%$ of cellulose, $26 \%$ of hemicellulose, and $16 \%$ of lignin (El-Masry 1983) can be one of the solutions for mitigating the emission of GHG in Egypt.

The aim of this search is to develop a way to manage the agriculture waste (rice straw) that causes environmental problems to an environmental cleaner material, used in water treatment process. The rice straw was converted into Biochar (p-Biochar) by burning in airless environment. The resulted product (p-Biochar) was activated by green method using the wet milling technique to give milled Biochar (m-Biochar). This active product was used to remove $\mathrm{MB}$ and $\mathrm{CV}$ dyes from aqueous solution.

\section{Experiment}

\section{Materials}

All chemicals were of analytical grade and used as received: methylene blue (MB) and crystal violet (CV) $(99.9 \%$, SigmaAldrich), and rice straw (Egyptian Nile delta region).

\section{Instrumentation}

Water distillatory (2108, GLF, Germany), pH meter (3510, Genway), hot plate stirrer (SB 162, Stuart, UK.), centrifuge, (Mikro 220R, Hettich, UK.) UV/Vis. spectrophotometer (Double beam) (T80+, PG instruments Ltd., UK.), analytical balance (CP 2245, Sartorius, USA.), and planetary ball mill (PM200, Retsch, Germany) are used during the experimental investigations.

\section{Preparation of Biochar}

The feedstock of rice straw was converted to biochar using the pyrolysis unit described by El-Gamal et al. (2017). The pyrolysis unit is equipped with two double-jacket drums. The cover of the external drum was supplied with chimney of $100 \mathrm{~cm}$ height. Rice straw materials were placed inside the stainless steel net in the internal jacket. Pyrolysis process lasted $2 \mathrm{~h}$ at $500{ }^{\circ} \mathrm{C}$ in the partial absence of oxygen. The produced biochar was then ground by porcelain mortar and sieved at $2.00 \mathrm{~mm}$.

\section{Preparation of milled Biochar (m-Biochar)}

Milled Biochar (m-Biochar) was prepared by charging of $7.0 \mathrm{~g}$ of pre-source Biochar (p-Biochar) in a laboratory scaled ball mill. Steel balls were used as milling media, steel vial was used as reactor, and the ball mill was adjusted at $400 \mathrm{rpm}$ on a "continuous mode". A milling period of $8 \mathrm{~h}$, media weight of $113 \mathrm{~g}$ and water volume of $50 \mathrm{ml}$ were taken as milling conditions. The produced $\mathrm{m}$-Biochar was filtrated and dried at $50{ }^{\circ} \mathrm{C}$ for $24 \mathrm{~h}$.

\section{Characterization}

The characterization of the p-Biochar and m-Biochar was carried out by a scanning electron microscope (SEM) (JSM636 OLA, Jeol, Japan) and Fourier transform infrared spectroscopy (FT-IR) (8400 s, Shimadzu, Japan) covering the range from 400 to $4000 \mathrm{~cm}^{-1}$. IR spectra of solid samples were detected using the $\mathrm{KBr}$ disk method. Porosity and pore size distribution of $\mathrm{p}$-Biochar and $\mathrm{m}$-Biochar samples were measured using a mercury porosimeter (Pore sizer 9320, micrometrics, USA). The surface areas were calculated by Brunauer-Emmett-Teller (BET) equations at $77 \pm 1 \mathrm{~K}$. The measurements were performed by a Quanta chrome NOVA automated gas sorption system using $\mathrm{N}_{2}$ gas as the adsorbate.

\section{Adsorption process}

The dye adsorption by m-Biochar was recorded and studied by detecting the variation of the color of the $\mathrm{MB}$ and $\mathrm{CV}$ dyes in an aqueous solution, under continuous stirring. We carried out the experiments by placing $50 \mathrm{ml}$ of the dye solution (MB and CV) in a $100-\mathrm{ml}$ glass beaker at various initial dye concentrations $(20,40,60,80$, and $100 \mathrm{ppm})$. Different amounts of m-Biochar $(0.010-0.050 \mathrm{mg})$ and the effect of contact time were demonstrated at time intervals (0.5-45 min). The salinity was tested by adding $\mathrm{NaCl}$ to the dye solution in the range of $0-0.5 \mathrm{~g}$, at temperatures of $25,35,45$ and $55^{\circ} \mathrm{C}$ and $\mathrm{pH}$ of $1.5,3.5,5,7,9.5,11.5$ for MB and $(2,3.5,5,7,9.5)$ for CV. Finally, $1.5 \mathrm{ml}$ of the suspension was removed and centrifuged. After phase separation, $1.0 \mathrm{ml}$ of the centrifuged solution was diluted to $5 \mathrm{ml}$ (for MB) and $10 \mathrm{ml}$ (for $\mathrm{CV}$ ) by distill water. $\mathrm{MB}$ and CV concentrations were determined at 662 and $590 \mathrm{~nm}$, respectively. 
The dye removal efficiency $(\% R)$ is defined as:

$\% R=\frac{\left(C_{\mathrm{o}}-C_{t}\right)}{C_{\mathrm{o}}} \times 100$

where $C_{\mathrm{o}}$ and $C_{t}$ are the initial concentration and the concentration of dye at time $t$, respectively.

\section{Results and discussion}

\section{Characterization}

\section{SEM-EDX analysis}

The surface morphology of p-Biochar and m-Biochar at various magnifications was investigated using SEM, as shown in Fig. 1. At low magnification, p-Biochar seems like the grooves-like structure, and as the magnification power increases, we observe the presence of grains in the surface of the grooves, as presented in Fig. 1a-g. On contrast, the grains possess different morphological structures which are scientifically seen by further magnification, as shown in Fig. 1d-g. As a result of the milling step, a great variation in the morphological structure of the modified biochar (m-Biochar) is observed, as shown in Fig. 1h-m. The $\mathrm{m}$-Biochar preformed as fine powder free from grooves, as shown in Fig. 1h-m. Furthermore, the extra magnification shows that the size of the scanned m-Biochar material highly reduced from compared with p-Biochar (Fig. 1m).

EDX analysis of origin ash straw, p-Biochar and m-Biochar is shown in Fig. $2 \mathrm{a}-\mathrm{c}$. The origin rice straw composed of mainly organic material (as proved from the high content of $\mathrm{C}$ and $\mathrm{O}$ ) and different levels of inorganic materials such as $\mathrm{Si}, \mathrm{K}, \mathrm{Cl}, \mathrm{Ca}, \mathrm{Mg}$, $\mathrm{Na}$ and $\mathrm{S}$ as shown in Fig. 2a. Carbonization of rice straw in inert atmosphere to produce $\mathrm{p}$-Biochar was confirmed by increasing the carbon content in the produced p-Biochar, as seen in Fig. 2b. On the other hand, there is an increase in the $\mathrm{O}$ content in the $\mathrm{m}$-Biochar sample obtained from the wet attrition of the $\mathrm{p}$-Biochar, as presented in Fig. 2c. Consequently, as expected the hydrophilicity and water dispersibility of m-Biochar will be enhanced compared with p-Biochar, as explained in Fig. 2d.

\section{FTIR}

FTIR spectra required determining various surface function groups for p-Biochar and m-Biochar, as pointed in Fig. 3. The shown absorption peak at $3437 \mathrm{~cm}^{-1}$ corresponds to O-H stretching vibration of the adsorbed water, the peak at $2931 \mathrm{~cm}^{-1}$ reveals $\mathrm{C}-\mathrm{H}$ stretching, the peak at $1627 \mathrm{~cm}^{-1}$ corresponds to the $\mathrm{C}=\mathrm{C}$ stretching (Kamal et al. 2017),
$1477 \mathrm{~cm}^{-1}$ is due to bending vibration of $\mathrm{CH}_{2}$ (Da Silva et al. 2018), and $1101 \mathrm{~cm}^{-1}$ is related to stretching $\mathrm{C}-\mathrm{O}$ bonds. FTIR spectrum of $\mathrm{m}$-Biochar shows the characteristic peaks obtained in p-Biochar with slightly shifted and more intense peaks. Moreover, after the treatment of the dyed water, the FTIR spectrum of the m-Biochar was highly alternated where the bands at $1095 \mathrm{~cm}^{-1}, 1460 \mathrm{~cm}^{-1}$ and $1624 \mathrm{~cm}^{-1}$, before the adsorption shifted to $1099 \mathrm{~cm}^{-1}, 1440 \mathrm{~cm}^{-1}$ and $1599 \mathrm{~cm}^{-1}$, after the adsorption, and became more intense as in Fig. 3. Additionally, two new bands appeared after the adsorption of MB dye $1332 \mathrm{~cm}^{-1}$ and $1390 \mathrm{~cm}^{-1}$ which may be related to the dye species. This affirms the adsorption of the dye and incorporation of the surface active groups in the adsorption process.

\section{Surface area and porosity}

The surface area pore diameters of $\mathrm{p}$-Biochar and m-Biochar are illustrated in Fig. 4a. The p-Biochar possesses high surface area $\left(223.4 \mathrm{~m}^{2} / \mathrm{g}\right)$ and large wide distribution in pore size within the range of 5-150 $\mu \mathrm{m}$. However, after the wet attrition process the surface area and the pore size of the released biochar ( $\mathrm{m}$-Biochar) were dramatically reduced to $104 \mathrm{~m}^{2} / \mathrm{g}$ and $0.5-5.0 \mu \mathrm{m}$, respectively (Fig. 4a). This affirms the formation of oxygenated active groups not only on the $\mathrm{m}$-Biochar surface but also inside the pores structure (Cao et al. 2016; Zhao et al. 2017), which was confirmed also by EDS analysis (Fig. 2), and FTIR spectra (Fig. 3). From the previous results, we can conclude that the wet attrition technique is a available tool for green activation process.

\section{Thermal analysis}

The thermal behavior of $\mathrm{p}$-Biochar and m-Biochar shows exothermic characteristics as presented in Fig. 4b. The exothermic peaks were located at $265{ }^{\circ} \mathrm{C}$ for $\mathrm{p}$-Biochar and $225^{\circ} \mathrm{C}$ for $\mathrm{m}$-Biochar. Moreover, the DSC curve indicated that the heat liberated in the case of p-Biochar suggests to be higher than that the heat liberated from m-Biochar. This maybe reveals the formation of $\mathrm{O}$-functional groups and reduction in the biochar size upon the wet milling process (Zhang et al. 2009; Zheng et al. 2014).

\section{Adsorption process}

\section{Effect of initial dye concentration}

The effect of initial concentration of MB and CV dyes on its removal percent $\% R$ aqueous solution is illustrated in Fig. 5a. It is observed that the $\% R$ decreases with the further increase in the initial concentration of MB and CV dyes. This phenomenon is: as the dye concentration increases, a

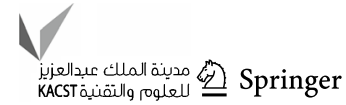



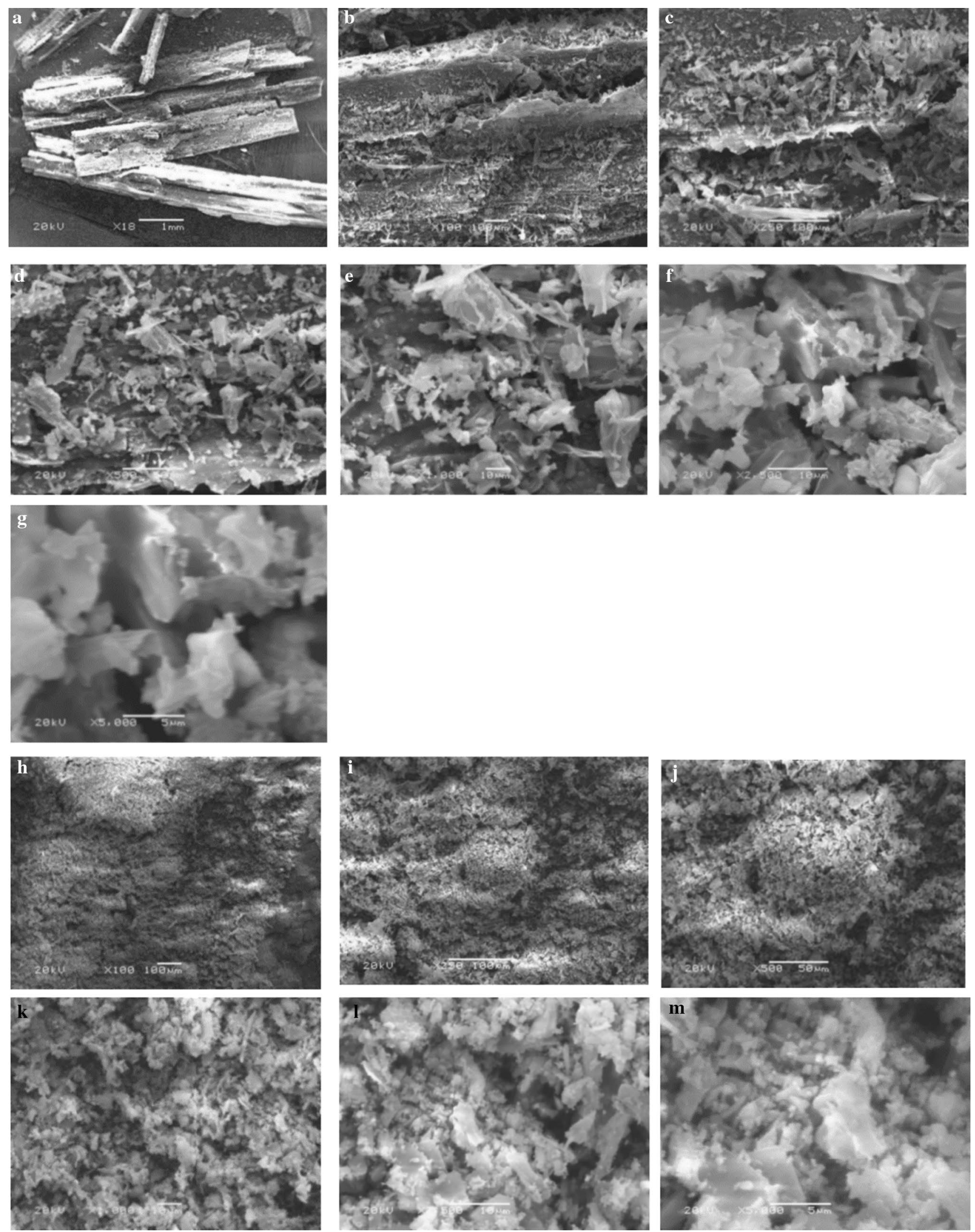

Fig. 1 The SEM images at various magnifications of the p-Biochar $(\mathbf{a}-\mathbf{g})$ and m-Biochar $(\mathbf{h}-\mathbf{m})$ 

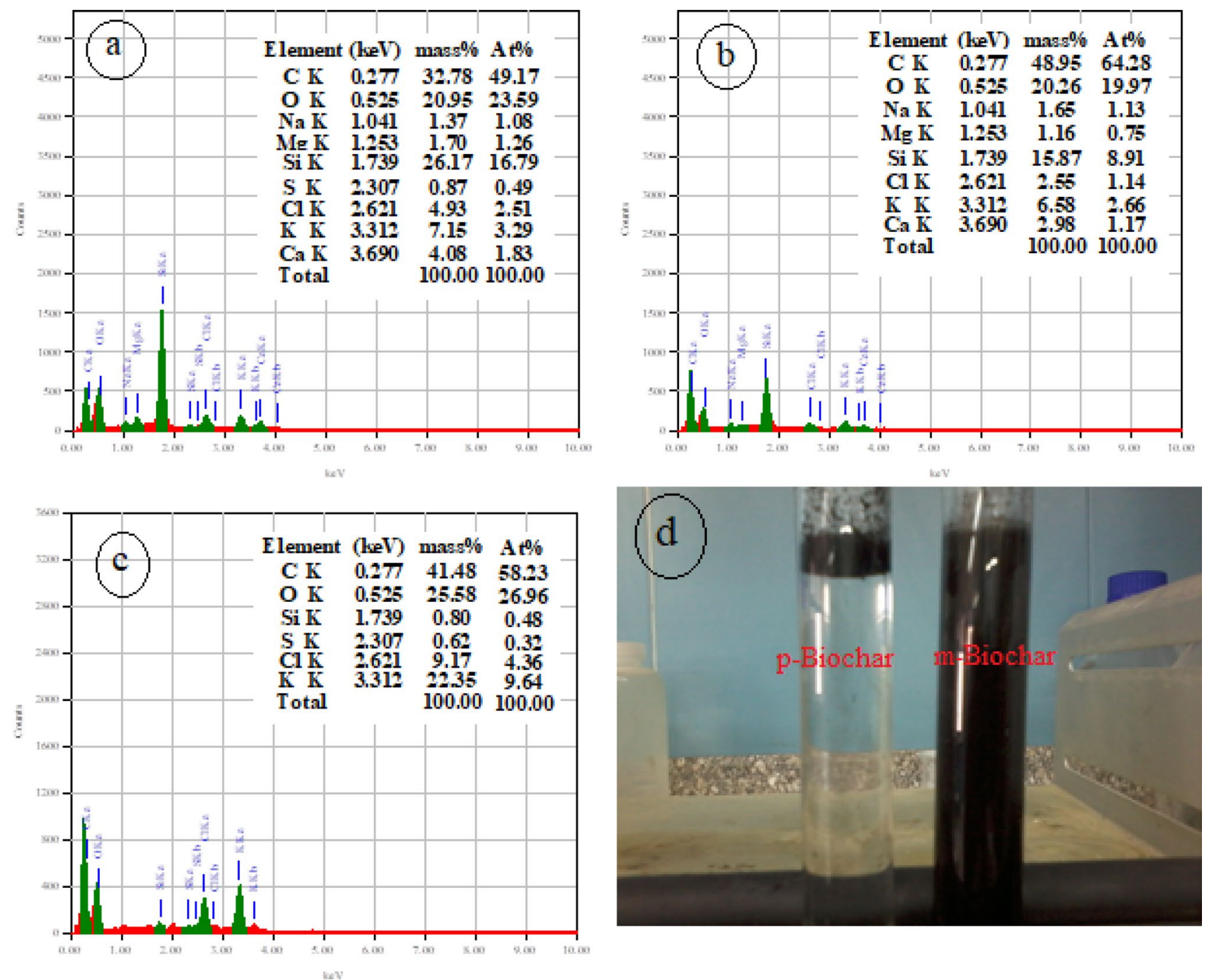

Fig. 2 EDX analysis of a origin ash straw, $\mathbf{b}$ p-Biochar, $\mathbf{c}$ m-Biochar and $\mathbf{d}$ the water dispersibility of p-Biochar and m-Biochar

large number of the dye species compete on a limited number of available active sites.

By fixation of the adsorbent dose, the active sites available for the adsorption process are limited. Consequently, using low concentration of the dye solution, the number of the active sites is sufficient for removal of all dye molecules. However, this limited number of active sites is available for the definite number of the dye species in the solution (Chatterjee et al. 2005; Chiou and Li 2003).

\section{Adsorption isotherm}

Adsorption isotherm model was utilized to study the relation among the quantity of adsorbed adsorbate $(\mathrm{mg})$ on the surface of adsorbent (g). Langmuir and Freundlich isotherms are the most famous models used for the description of the adsorption isotherm.
Langmuir isotherm This model suggests monolayer adsorption of adsorbate species on equally energetic active sites of adsorbate, and its mathematical expression is represented in Eq. 2.

$\frac{C_{\mathrm{e}}}{q_{\mathrm{e}}}=\left(\frac{1}{b q^{\mathrm{o}}}\right)+\left(\frac{1}{q^{\mathrm{o}}}\right) C_{\mathrm{e}}$

where $C_{\mathrm{e}}$ is the equilibrium concentration $(\mathrm{mg} / \mathrm{L}), q_{\mathrm{e}}$ is the amount adsorbed at equilibrium time $(\mathrm{mg} / \mathrm{g}), q^{\mathrm{o}}$ is the maximum dye species uptake per unit mass of adsorbent $(\mathrm{mg} / \mathrm{g})$, which is related to adsorption capacity and $b$ is Langmuir constant $(\mathrm{L} / \mathrm{mol})$.

The equilibrium parameter, $R_{\mathrm{L}}$, is a dimensionless constant which characteristic Langmuir isotherm, can be expressed by Eq. 3 . 


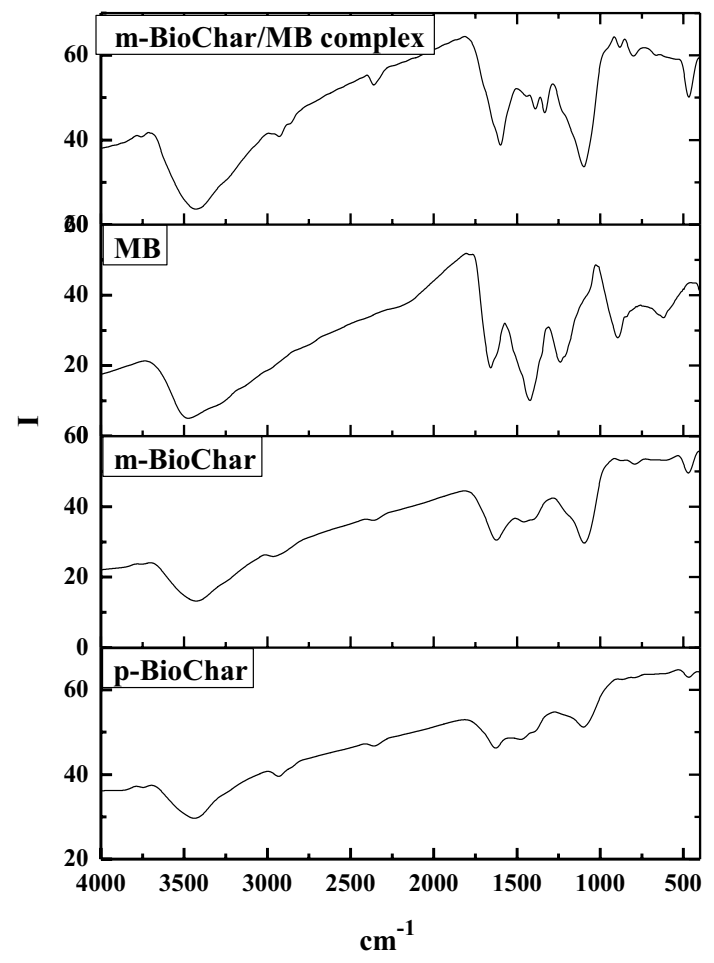

Fig. 3 FTIR spectrum of p-Biochar, m-Biochar, MB dye, and m-Biochar-MB dye complex

$R_{\mathrm{L}}=\frac{1}{1+b C_{\mathrm{o}}}$

where $C_{\mathrm{o}}$ is the initial dye concentration. The nature of the adsorption process can be either unfavorable $\left(R_{\mathrm{L}}>1\right)$, linear $\left(R_{\mathrm{L}}=1\right)$, favorable $\left(0<R_{\mathrm{L}}<1\right)$, or irreversible $\left(R_{\mathrm{L}}=0\right)$.

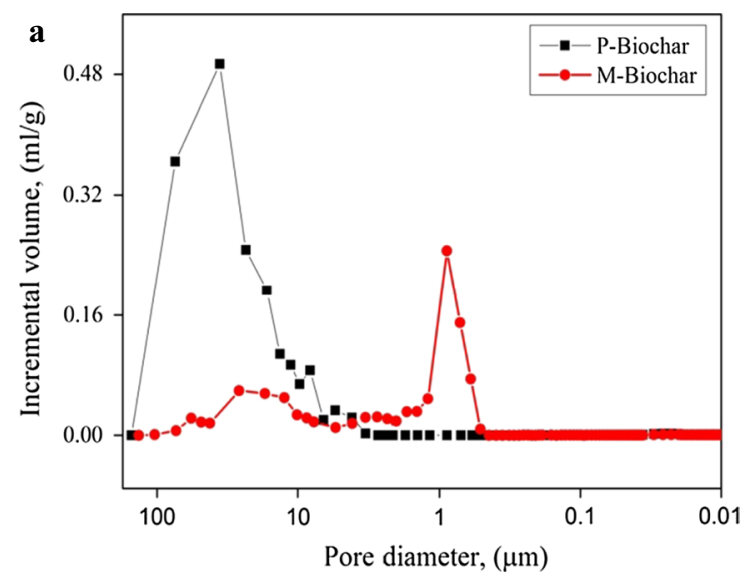

Freundlich isotherm Freundlich model assumes that the adsorbate species were adsorbed on hetero-energetic active sites of the adsorbent and could be presented by Eq. 4 .

$\log q_{\mathrm{e}}=\log K_{\mathrm{f}}+\frac{1}{n} \log C_{\mathrm{e}}$

$K_{\mathrm{f}}(\mathrm{mg} / \mathrm{g})$ and $n$ are Freundlich constants incorporating all factors affecting the adsorption process such as adsorption capacity and intensity of adsorption.

The experimental parameters resulting from linear plotting of Langmuir and Freundlich model (Fig. 5c) were calculated and are listed in Table 1. On comparing the values of correlation coefficient $R^{2}$ of the two models, it can be concluded that the adsorption of MB and CV dyes on the surface of m-Biochar follows Langmuir model; this means the adsorption process takes place on a homogenous active sites as a monolayer. Moreover, $R_{\mathrm{L}}$ values (Fig. 5d) lay between 0.0 and 1.0 proving a favorable adsorption of $\mathrm{MB}$ and $\mathrm{CV}$ over $\mathrm{m}$-Biochar.

\section{Effect of adsorbent dosage}

The effect of solid dosage in the range of $0.01-0.05 \mathrm{~g}$ on the removal percent for both MB and CV dye was demonstrated in Fig. 6. This figure shows that the removal percent increases from 34.70 to $95.06 \%$ for MB and from 29.32 to 95.13\% for $\mathrm{CV}$ when the adsorbent dose increases from 0.01 to $0.05 \mathrm{~g}$; this increase in $\% R$ can be explained by improving adsorbent surface area and rising in the available active sites for the adsorption (Da Silva et al. 2018).

\section{Effect of contact time}

The adsorption process is highly affected by the time spent where the adsorbent and adsorbate are in contact. The adsorption performance of $\mathrm{MB}$ and $\mathrm{CV}$ dyes on $\mathrm{p}$-Biochar

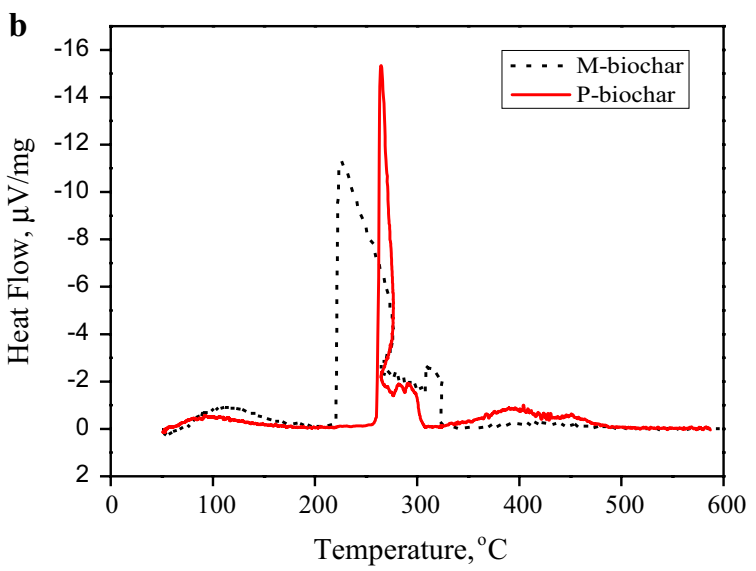

Fig. 4 a Pore size distribution and b DTA curve of p-Biochar and m-Biochar 
Fig. 5 a Effect of dye concentration on removal percent of MB dye and CV dye, b Langmuir isotherm plots for removal of $\mathrm{MB}$ and $\mathrm{CV}$ dyes, $\mathbf{c}$ separation factor $\left(R_{\mathrm{L}}\right)$ and $\mathbf{d}$ Freundlich isotherm plots for removal $\mathrm{MB}$ and $\mathrm{CV}$ dyes from pure water by $\mathrm{m}$-AS. $\mathrm{MB} \rightarrow \mathrm{m}$-AS dose $=0.03 \mathrm{~g}$, time $=10 \mathrm{~min}$., $T=25^{\circ} \mathrm{C}, \mathrm{pH}=7, t=10 \mathrm{~min}$, $V=50 \mathrm{ml} ; \mathrm{CV} \rightarrow \mathrm{m}-\mathrm{AS}$ dose $=0.03 \mathrm{~g}$, time $=10 \mathrm{~min}$., $T=25^{\circ} \mathrm{C}, \mathrm{pH}=7, t=10 \mathrm{~min}$, $V=50 \mathrm{ml}$
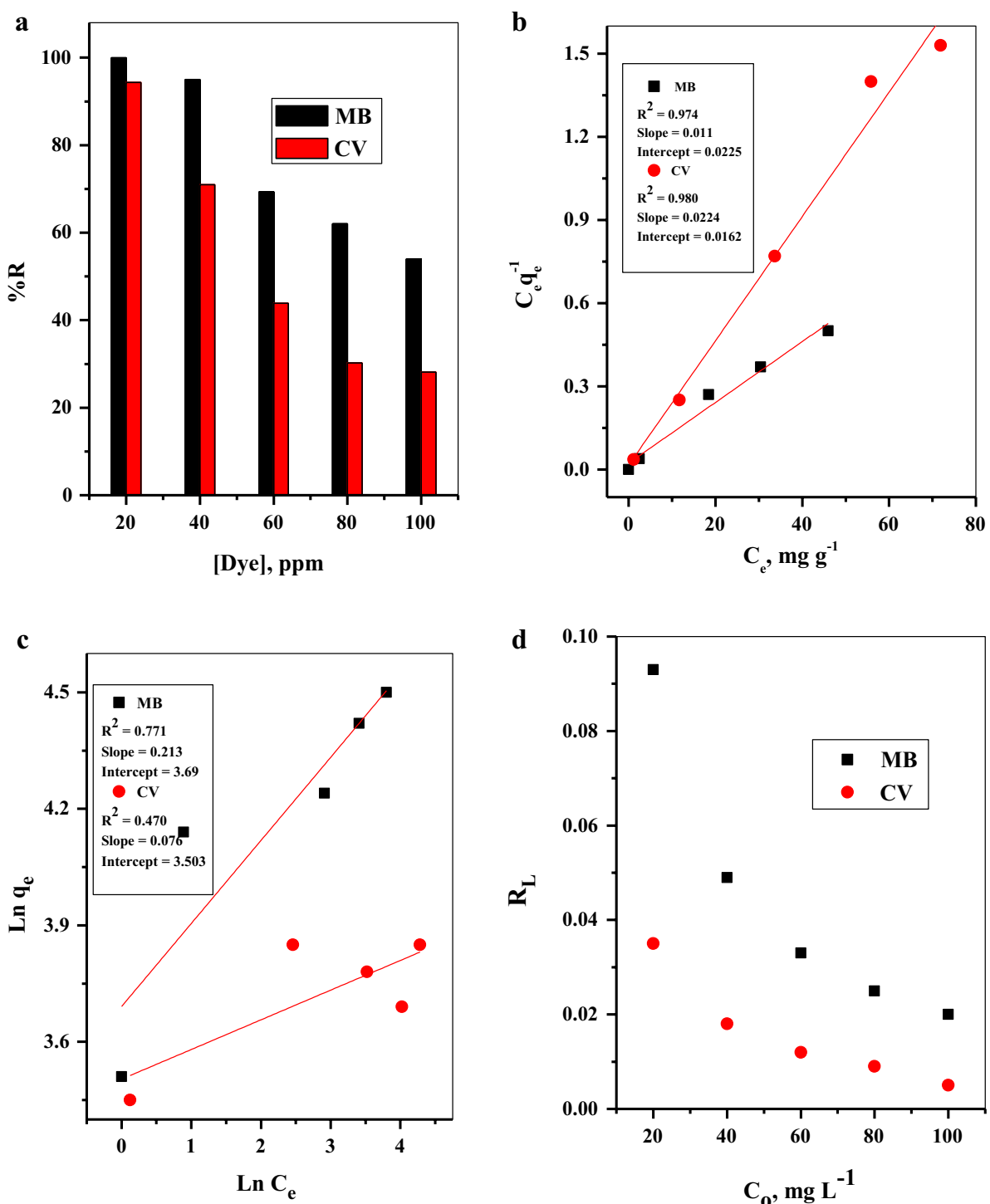

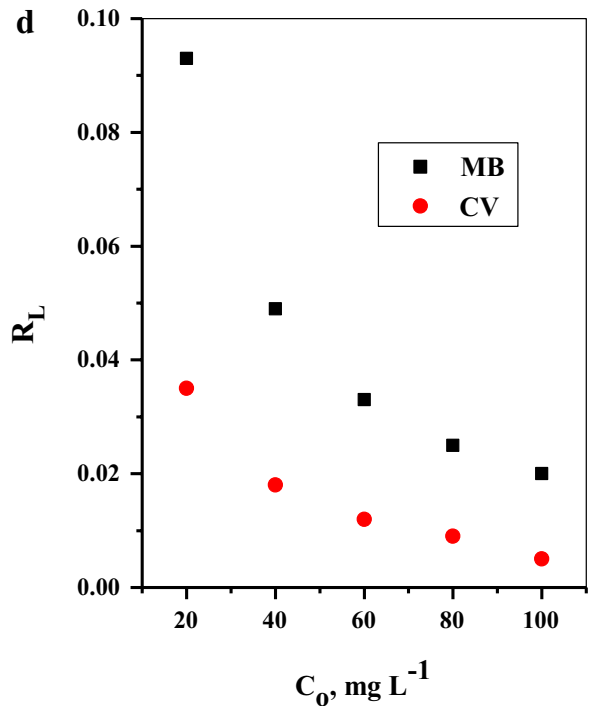

Table 1 Calculated equilibrium constants for adsorption of CV on composite

\begin{tabular}{llllllll}
\hline Dye & \multicolumn{2}{l}{ Langmuir isotherm model } & & \multicolumn{4}{l}{ Freundlich isotherm model } \\
\cline { 2 - 3 } & $Q^{\mathrm{o}}(\mathrm{mg} / \mathrm{g})$ & $b(\mathrm{l} / \mathrm{mg})$ & $R^{2}$ & & $1 / n$ & $K_{\mathrm{f}}(\mathrm{mg} / \mathrm{g})$ & $R^{2}$ \\
\hline MB & 90.91 & 0.49 & 0.974 & & 0.213 & 40.04 & 0.771 \\
$\mathrm{CV}$ & 44.64 & 1.38 & 0.980 & & 0.076 & 33.21 & 0.470 \\
\hline
\end{tabular}

and $\mathrm{m}$-Biochar was detected at time intervals $0.5-45 \mathrm{~min}$, as seen in Fig. 7a. It is obvious that at utilizing p-Biochar the removal percent for both two dyes is very weak. On the other hand, the $\% R$ is enhanced in the case of presence of m-Biochar. Where $84.13 \%$ and $73.81 \%$ removed from MB and CV dye aqueous solution in $0.5 \mathrm{~min}$, respectively. Moreover, the equilibrium was reached for MB (94.45\%) in $15 \mathrm{~min}$ and CV $(92.70 \%)$ in $20 \mathrm{~min}$. This behavior can be explained on basis that the wet attrition makes reduction in the particle size (SEM images) and adds extra O-active groups (FTIR and porosity sections), which leads to increase the activity, hydrophilicity and the water dispersibility of m-Biochar compared with p-Biochar.

\section{Adsorption kinetics}

The relationship between the adsorption rate of the adsorbate and the adsorption time is explained by using adsorption kinetics. Two well-known kinetic models, pseudo-first-order presented by Lagergren equation (Lagergren 1898) Eq. 5. 


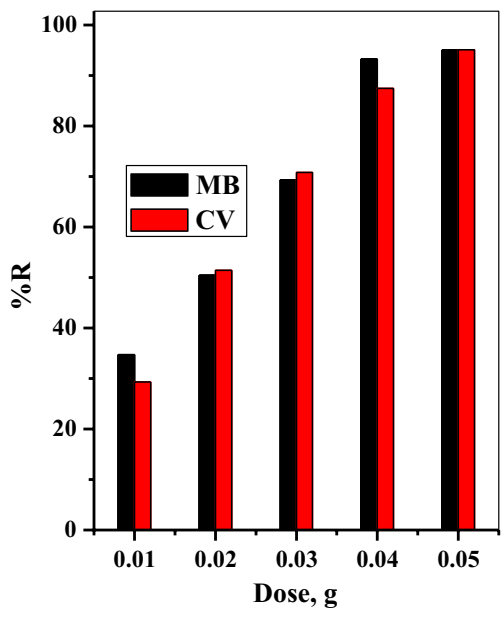

Fig. 6 Effect of m-Biochar dose on removal percent of MB and CV dyes from pure water. $\mathrm{MB} \rightarrow[\mathrm{MB}]=60 \mathrm{ppm}, T=25{ }^{\circ} \mathrm{C}, \mathrm{pH}=7$, $t=10 \mathrm{~min}, V=50 \mathrm{ml} ; \mathrm{CV} \rightarrow[\mathrm{CV}]=40 \mathrm{ppm}, T=25^{\circ} \mathrm{C}, \mathrm{pH}=7$, $t=10 \mathrm{~min}, V=50 \mathrm{ml}$ $\log \left(q_{\mathrm{e}}-q_{t}\right)=\log q_{\mathrm{e}}+\frac{K_{\mathrm{ads}} t}{2.303}$

where $q_{\mathrm{e}}(\mathrm{mg} / \mathrm{g})$ is the amount of sorption at equilibrium time, $q_{t}(\mathrm{mg} / \mathrm{g})$ is amount of sorption at time, and $K_{\text {ads }}$ $\left(\mathrm{min}^{-1}\right)$ is the rate constant of pseudo-first-order sorption.

$q_{\mathrm{e}}=\frac{\left(C_{\mathrm{o}}-C_{\mathrm{e}}\right) V}{1000 w}$

where $C_{\mathrm{o}}$ is the initial concentration $(\mathrm{mg} / \mathrm{L}), C_{\mathrm{e}}$ is the dye concentration at equilibrium time intervals $(\mathrm{mg} / \mathrm{L}), V$ is the volume of dye solution ( $\mathrm{mL}$ ), and $w$ is the mass of adsorbent (g)

$q_{t}=\frac{\left(C_{o}-C_{t}\right) V}{1000 w}$

where $C_{t}$ is the dye concentration at different time intervals $(\mathrm{mg} / \mathrm{L})$.
Fig. 7 a Effect of contact time on removal percent of $\mathrm{MB}$ and CV dyes, $\mathbf{b}$ Lagergren plots for removal of $\mathrm{MB}$ and $\mathrm{CV}$ dyes and $\mathbf{c}$ pseudo-second-order plot for removal of $\mathrm{MB}$ and $\mathrm{CV}$ dyes from pure water by m-Biochar. $\mathrm{MB} \rightarrow[\mathrm{MB}]=60 \mathrm{ppm}$, dose $=0.04 \mathrm{~g}, T=25^{\circ} \mathrm{C}$, $\mathrm{pH}=7, V=50 \mathrm{ml}$; $\mathrm{CV} \rightarrow[\mathrm{CV}]=40 \mathrm{ppm}$, dose $=0.04 \mathrm{~g}, T=25^{\circ} \mathrm{C}, \mathrm{pH}=7$, $V=50 \mathrm{ml}$ a

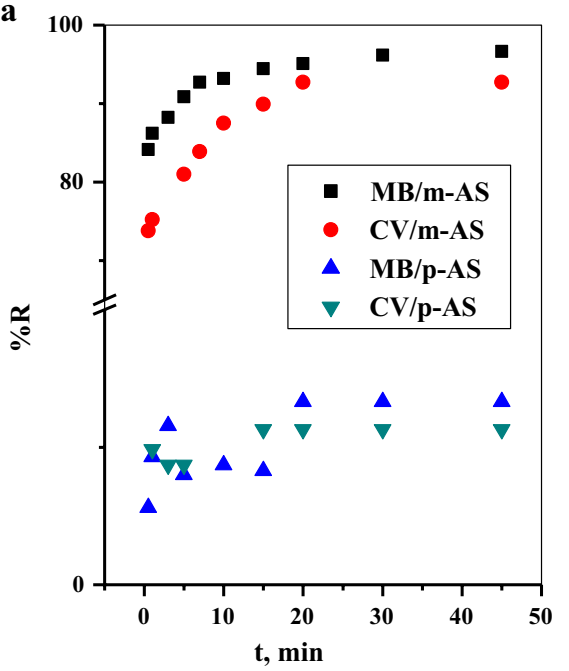

c

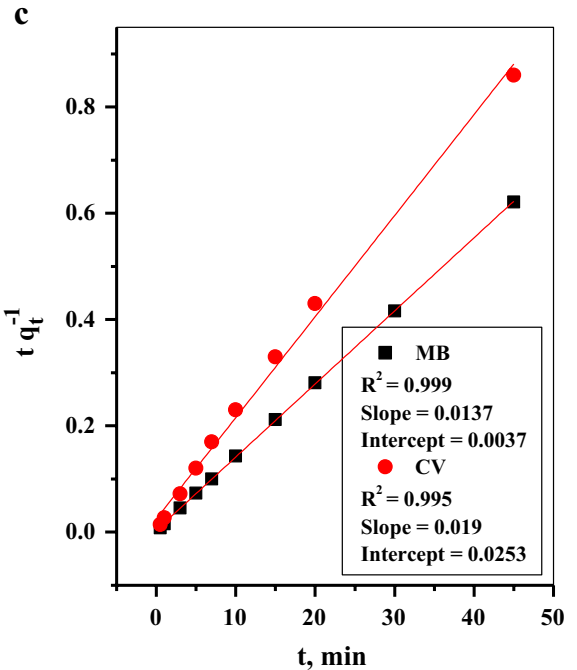

b

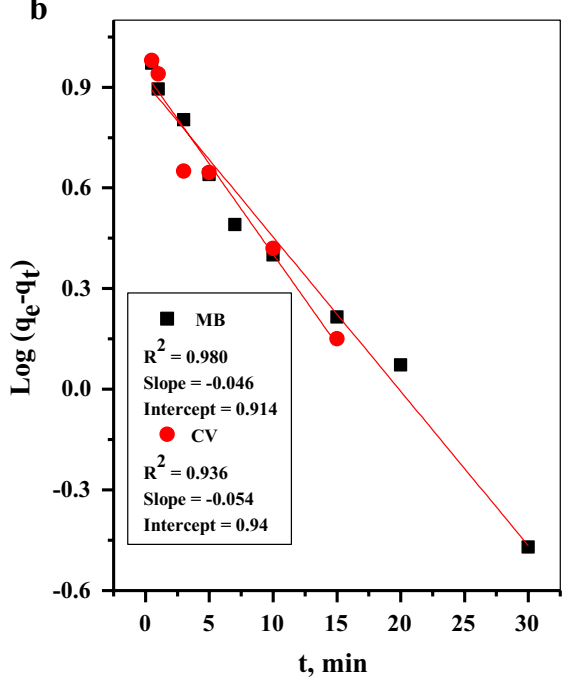


And pseudo-second-order expressed by Ho equation (Ho and McKay 1999) the equation developed in a linear form as Eq. 8:

$\frac{t}{q_{t}}=\frac{1}{K_{2} q_{\mathrm{e}}^{2}}+\frac{t}{q_{\mathrm{e}}}$

where $K_{2}(\mathrm{~g} / \mathrm{mg} \mathrm{min})$ is the rate constant of reaction.

The various parameters result from analyzing the kinetic models; pseudo-first order (Fig. 7b) pseudo-second order (Fig. 7c) were calculated and are recorded in Table 2. Based on the parameter values obtained from different models, it is clearly that the pseudo-second-order kinetic model gives high coefficient factor $\left(R^{2}\right)$ values i.e., 0.999 (for MB) and 0.995 (for $\mathrm{CV}$ ), and the calculated $q_{\mathrm{e}}$ is equal to 72.99 (for $\mathrm{MB}$ ) and 52.63(for $\mathrm{CV}$ ) which is more closer to the experimental value, $q_{\mathrm{e}}$, of 72.48 and 46.38 for $\mathrm{MB}$ and $\mathrm{CV}$, respectively. This makes the adsorption of both dyes on the m-AS follow the pseudo-second-order kinetic model.
Table 2 Calculated parameters pseudo-second-order kinetic models of batch of the pseudo-first-order and

\begin{tabular}{|c|c|c|c|c|c|c|c|}
\hline \multirow[t]{2}{*}{ Dye } & \multirow[t]{2}{*}{$q_{\mathrm{e} \exp }(\mathrm{mg} / \mathrm{g})$} & \multicolumn{3}{|c|}{ First-order kinetic parameter } & \multicolumn{3}{|c|}{ Second-order kinetic parameter } \\
\hline & & $\overline{K_{1}\left(\min ^{-1}\right)}$ & $q_{\mathrm{e} \text { cal }}(\mathrm{mg} / \mathrm{g})$ & $R^{2}$ & $\overline{K_{2}(\mathrm{~g} / \mathrm{mg} \min )}$ & $q_{\mathrm{e} \text { cal }}(\mathrm{mg} / \mathrm{g})$ & $R^{2}$ \\
\hline MB & 72.48 & -0.106 & 8.20 & 0.980 & 0.051 & 72.99 & 0.999 \\
\hline $\mathrm{CV}$ & 46.38 & -0.124 & 8.71 & 0.936 & 0.014 & 52.63 & 0.995 \\
\hline
\end{tabular}

Fig. 8 a Effect of $\mathrm{NaCl}$ dose on removal percent of MB dye $(t=15 \mathrm{~min},[\mathrm{~m}-\mathrm{AS}]=0.04 \mathrm{~g}$, $[\mathrm{MB}]=60 \mathrm{ppm}, \mathrm{pH}=7$, $T=25^{\circ} \mathrm{C}$ ) and $\mathrm{CV}$ dye $(t=20 \mathrm{~min}$, [m-Biochar $]=0.04 \mathrm{~g},[\mathrm{CV}]=40 \mathrm{ppm}$, $\mathrm{pH}=7, T=25^{\circ} \mathrm{C}$ ) from pure water. b Effect of temperature on removal percent of MB dye $(t=15 \mathrm{~min}$, $[\mathrm{m}-$ Biochar $]=0.04 \mathrm{~g}$, $[\mathrm{MB}]=60 \mathrm{ppm}, \mathrm{pH}=7)$ and $\mathrm{CV}$ dye $(t=20 \mathrm{~min}$, [m-Biochar $]=0.04 \mathrm{~g},[\mathrm{CV}]=40 \mathrm{ppm}$, $\mathrm{pH}=7$ ) from pure water. c Effect of $\mathrm{pH}$ on removal percent of MB dye $(t=15 \mathrm{~min}$, $[\mathrm{m}-$ Biochar $]=0.04 \mathrm{mg}$, $\left.[\mathrm{MB}]=60 \mathrm{ppm}, T=25^{\circ} \mathrm{C}\right)$ and CV dye ( $t=20 \mathrm{~min}$, [m-Biochar $]=0.04 \mathrm{~g},[\mathrm{CV}]=40 \mathrm{ppm}$, $T=25^{\circ} \mathrm{C}$ ) from pure water
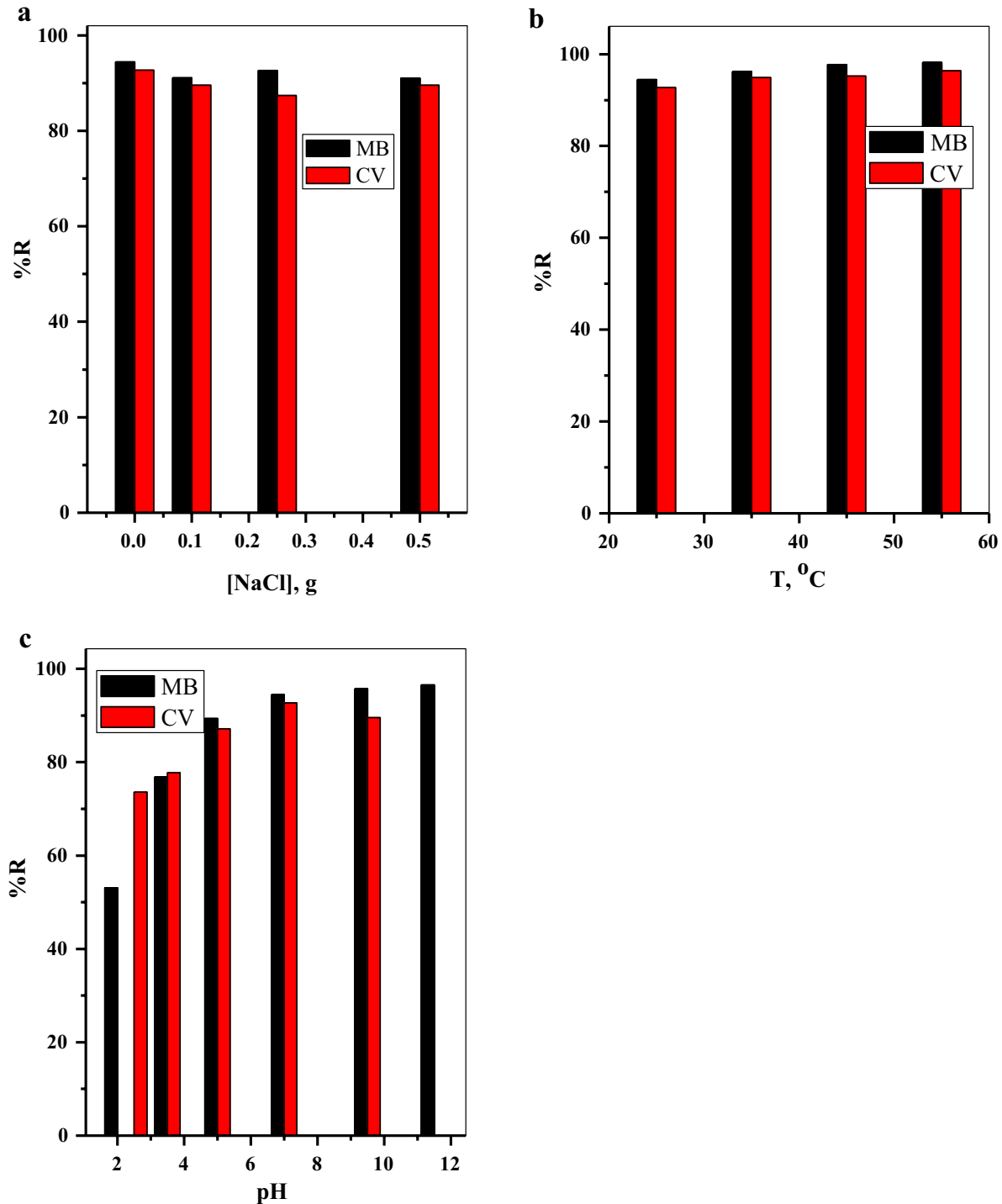
Table 3 Langmuir-based maximum adsorption capacity of several adsorbents for $\mathrm{MB}$ and $\mathrm{CV}$ dye adsorption

\begin{tabular}{llll}
\hline Adsorbent & Dye & $\begin{array}{l}\text { Adsorption capacity } \\
(\mathrm{mg} / \mathrm{g})\end{array}$ & References \\
\hline Yellow passion fruit waste & MB & 44.70 & Pavan et al. (2008) \\
Rice husks & MB & 40.60 & Vadivelan and Kumar (2005) \\
Banana peel & MB & 20.80 & Annadurai et al. (2002) \\
Cereal chaff & MB & 20.30 & Han et al. (2006) \\
Wheat shells & MB & 16.60 & Bulut and Aydin (2006) \\
Posidonia oceanica (L.) fibers & MB & 5.60 & Ncibi et al. (2007) \\
m-Biochar & MB & 90.91 & This study \\
Jute fiber carbon & CV & 28.00 & Porkodi and Kumar (2007) \\
Coniferous pinus bark powder & CV & 32.78 & Ahmad (2009) \\
Clay & CV & 17.05 & Miyah et al (2017) \\
Orange peel & CV & 14.30 & Mushtaq et al (2016) \\
Sugarcane fiber & CV & 10.44 & Parab et al. (2009) \\
m-Biochar & CV & 44.64 & This study \\
\hline
\end{tabular}

\section{Effect of $\mathrm{NaCl}$ dose and temperature}

The effect of $\mathrm{NaCl}$ dose in the range of $0.00-0.50 \mathrm{~g}$ and temperature in the range of $25-55^{\circ} \mathrm{C}$ on the removal percent of MB and CV dyes was studied as shown in Fig. 8a-b. Clearly, the increase in the dose of the $\mathrm{NaCl}$ or the temperature resulted in a slight variation in the $\% R$ for both $\mathrm{MB}$ and $\mathrm{CV}$ dyes.

\section{Effect of initial pH}

The variation in the initial $\mathrm{pH}$ of the solution is strongly influenced on the nature of adsorbent active sites and adsorbate species. As expected, the removal percent $\% R$ of $\mathrm{MB}$ and $\mathrm{CV}$ from the aqueous solution was alerted with any variation of the solution $\mathrm{pH}$, as shown in Fig. 8c. We can see the adsorption increases by increasing the $\mathrm{pH}$ values. $\mathrm{MB}$ and $\mathrm{CV}$ are cationic dyes, i.e., having positive charge; in this trend, at low values of $\mathrm{pH}, \mathrm{H}$-ions compete with the dye species to be adsorbed on adsorption active site; this leads to decreasing the removal percent of both dyes. Increasing the $\mathrm{pH}$ values makes the competition weak which enhances the adsorption percent (Shoukat et al. 2017).

\section{Comparison of dye removal with different adsorbents reported in literature}

Several reports have been developed for preparation adsorbents from various agriculture waste materials and studying its activity toward removal of $\mathrm{MB}$ and $\mathrm{CV}$ dyes from aqueous solution. The adsorption capacities of these adsorbents were recorded and compared with m-Biochar prepared in this study (Table 3). The data presented that the adsorbent used in this study shows adsorption capacity higher than that of the other adsorbents.

\section{Conclusion}

We successfully prepared an economic, efficient, and green activation adsorbent material derived from a waste agriculture product. The prepared adsorbent was used to treat the dyed waste effluents. The experimental results obtained estimated that the adsorbent used (m-Biochar) is an efficient adsorbent for removal of $\mathrm{MB}$ and $\mathrm{CV}$ dyes from aqueous solution. According to Langmuir isotherm, the maximum adsorption capacity of MB is $90.91 \mathrm{mg} / \mathrm{g}$ and $\mathrm{CV}$ is $44.64 \mathrm{mg} / \mathrm{g}$, and the two dyes were adsorbed as a monolayer on the adsorbent. The kinetic adsorption data of both used dyes flow the pseudo-second-order model. The solution $\mathrm{pH}$ highly controls the adsorption of the two dyes. Moreover, the removal percent of the two dyes is not influenced by the rising in the temperature or the $\mathrm{NaCl}$ dose.

Finally, this research exhibits an excellent environmental solution. Where, $\mathrm{m}$-Biochar prepared from rice straw using simple, economic preparation routs. On the other hand, the resulted adsorbent is used to remove the cationic dyes from aqueous solutions.

Acknowledgements I would like to thank all the groups that aid in this work.

\section{Compliance with ethical standard}

Conflict of interest The authors have no conflict of interest.

Open Access This article is licensed under a Creative Commons Attribution 4.0 International License, which permits use, sharing, adaptation, distribution and reproduction in any medium or format, as long as you give appropriate credit to the original author(s) and the source, provide a link to the Creative Commons licence, and indicate if changes were made. The images or other third party material in this article are included in the article's Creative Commons licence, unless indicated otherwise in a credit line to the material. If material is not included in 
the article's Creative Commons licence and your intended use is not permitted by statutory regulation or exceeds the permitted use, you will need to obtain permission directly from the copyright holder. To view a copy of this licence, visit http://creativecommons.org/licenses/by/4.0/.

\section{References}

Ahma MA, Rahman NK (2011) Equilibrium, kinetics and thermodynamic of Remazol Brilliant Orange 3R dye adsorption on coffee husk-based activated carbon. Chem Eng J 170:154-161

Ahmad R (2009) Studies on adsorption of crystal violet dye from aqueous solution onto coniferous pinus bark powder (CPBP). J Hazard Mater 171(1-3):767-773

Aljeboree AM, Alshirifi AN, Alkaim AF (2017) Kinetics and equilibrium study for the adsorption of textile dyes on coconut shell activated carbon. Arab J Chem 10:S3381-S3393

Annadurai G, Juang RS, Lee DJ (2002) Use of cellulose-based wastes for adsorption of dyes from aqueous solutions. J Hazard Mater 92(3):263-274

Bulut Y, Aydin H (2006) A kinetics and thermodynamics study of methylene blue adsorption on wheat shells. Desalination 194(1-3):259-267

Cao L, Zhang H, Cao C, Zhang J, Li F, Huang Q (2016) Quaternized chitosan-capped mesoporous silica nanoparticles as nanocarriers for controlled pesticide release. Nanomaterials 6(7):126

Chatterjee S, Chatterjee S, Chatterjee BP, Das AR, Guha AK (2005) Adsorption of a model anionic dye, eosin $\mathrm{Y}$, from aqueous solution by chitosan hydrobeads. J Colloid Interface Sci 288(1):30-35

Chiou MS, Li HY (2003) Adsorption behavior of reactive dye in aqueous solution on chemical cross-linked chitosan beads. Chemosphere 50(8):1095-1105

Da Silva JS, da Rosa MP, Beck PH, Peres EC, Dotto GL, Kessler F, Grasel FS (2018) Preparation of an alternative adsorbent from Acacia Mearnsii wastes through acetosolv method and its application for dye removal. J Clean Prod 180:386-394

El-Gamal EH, Saleh M, Elsokkary I, Rashad M, El-Latif MMA (2017) Comparison between properties of biochar produced by traditional and controlled pyrolysis. Alex Sci Exch J 38:412-425

El-Masry HG (1983) Utilisation of Egyptian rice straw in production of celluloses and microbial protein: effect of various pretreatments on yields of protein and enzyme activity. J Sci Food Agric 34(7):725-732

Foo KY, Hameed BH (2012) Coconut husk derived activated carbon via microwave induced activation: effects of activation agents, preparation parameters and adsorption performance. Chem Eng J 184:57-65

Gecgel U, Kolancilar H (2012) Adsorption of remazol brilliant blue $\mathrm{R}$ on activated carbon prepared from a pine cone. Nat Prod Res 26:659-664

Gupta VK (2009) Application of low-cost adsorbents for dye removal: a review. J Environ Manag 90:2313-2342

Han R, Wang Y, Han P, Shi J, Yang J, Lu Y (2006) Removal of methylene blue from aqueous solution by chaff in batch mode. J Hazard Mater 137(1):550-557

Ho YS, McKay G (1999) The sorption of lead (II) ions on peat. Water Res 33(2):578-584
Kamal MA, Bibi S, Bokhari SW, Siddique AH, Yasin T (2017) Synthesis and adsorptive characteristics of novel chitosan/graphene oxide nanocomposite for dye uptake. React Funct Polym 110:21-29

Khaled A, El Nemr A, Ei-Sikaily A, Abdelwahab A (2009) Treatment of artificial textile dye effluent containing direct yellow 12 by orange peel carbon. Desalination 238:210-232

Kobylewski S, Jacobson MF (2010) Food dyes: a rainbow of risks. Center for Science in the Public Interest, Washington

Lagergren SK (1898) About the theory of so-called adsorption of soluble substances. Sven Vetenskapsakad Handingarl 24:1-39

Miyah Y, Lahrichi A, Idrissi M, Anis K, Kachkoul R, Idrissi N, Zerrouq F (2017) Removal of cationic dye "crystal violet" in aqueous solution by the local clay. JMES 8(10):3570-3582

Mushtaq M, Bhatti HN, Iqbal M, Noreen S (2016) Eriobotrya japonica seed biocomposite efficiency for copper adsorption: isotherms, kinetics, thermodynamic and desorption studies. J Environ Manag 176:21-33

Ncibi MC, Mahjoub B, Seffen M (2007) Kinetic and equilibrium studies of methylene blue biosorption by Posidonia oceanica (L.) fibres. J Hazard Mater 139(2):280-285

Parab H, Sudersanan M, Shenoy N, Pathare T, Vaze B (2009) Use of agro-industrial wastes for removal of basic dyes from aqueous solutions. Clean-Soil Air Water 37(12):963-969

Pavan FA, Lima EC, Dias S, Mazzocato AC (2008) Methylene blue biosorption from aqueous solutions by yellow passion fruit waste. J Hazard Mater 150(3):703-712

Porkodi K, Kumar KV (2007) Equilibrium, kinetics and mechanism modeling and simulation of basic and acid dyes sorption onto jute fiber carbon: eosin yellow, malachite green and crystal violet single component systems. J Hazard Mater 143(1-2):311-327

Rahman MA, Amin SR, Alam AS (2012) Removal of methylene blue from waste water using activated carbon prepared from rice husk. Dhaka Univ J Sci 60(2):185-189

Senthilkumaar S, Kalaamani P, Subburaam CV (2006) Liquid phase adsorption of crystal violet onto activated carbons derived from male flowers of coconut tree. J Hazard Mater 136:800-808

Shoukat S, Bhatti HN, Igbal M, Noreen S (2017) Mango stone biocomposite preparation and application for crystal violet adsorption: a mechanistic study. Microporous Mesoporous Mater 239:180-189

Srinivasan A, Viraraghavan T (2009) Decolorization of dye wastewaters by biosorbents: a review. J Environ Manag 91:1915-1929

Vadivelan V, Kumar KV (2005) Equilibrium, kinetics, mechanism, and process design for the sorption of methylene blue onto rice husk. J Colloid Interface Sci 286(1):90-100

Zhang L, Liang J, Huang Y, Ma Y, Wang Y, Chen Y (2009) Sizecontrolled synthesis of graphene oxide sheets on a large scale using chemical exfoliation. Carbon 47(14):3365-3368

Zhao Y, Ren J, Tan T, Babaa MR, Bakenov Z, Liu N, Zhang Y (2017) biomass waste inspired highly porous carbon for high performance lithium/sulfur batteries. Nanomaterials 7(9):260

Zheng JN, Li SS, Ma X, Chen FY, Wang AJ, Chen JR, Feng JJ (2014) Popcorn-like PtAu nanoparticles supported on reduced graphene oxide: facile synthesis and catalytic applications. J Mater Chem A 2(22):8386-8395

Publisher's Note Springer Nature remains neutral with regard to jurisdictional claims in published maps and institutional affiliations. 